\title{
Kaizen for Small- and Medium-Sized Enterprises in Vietnam
}

\author{
Vu Hoang Nam, Nguyen Thi Tuong Anh, \\ and Doan Quang Hung
}

\section{INTRODUCTION}

Recent studies have found that enterprises in developing countries are more poorly managed than those in developed countries (Bloom et al. 2012). To see whether business management can be improved in the developing countries, randomized controlled trials (RCTs) have been conducted (Karlan and Valdivia 2011). McKenzie and Woodruff's (2014) survey of the literature observes that training programs are in many cases found to have marginally significant impacts on business performance. A possible explanation is that training impact varies depending on the content and other practicalities of the training program (e.g., Drexler et al. 2014).

In these studies, training content is often a certain variation of the International Labour Organization's (ILO) training curriculum "Start and Improve your Business (SIYB)," which emphasizes entrepreneurship, marketing, buying, stock control, and record-keeping. Production management and quality control, such as lean manufacturing and Kaizen

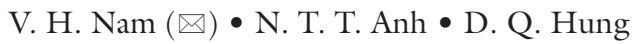

Faculty of International Economics, Foreign Trade University,

Hanoi, Vietnam

e-mail: namvh@ftu.edu.vn; tuonganh@ftu.edu.vn; hungdq@ftu.edu.vn

(C) The Author(s) 2020

A. Hosono et al. (eds.), Workers, Managers, Productivity, https://doi.org/10.1007/978-981-15-0364-1_11 
management, have seldom been covered. Exceptions include the training programs associated with the studies by Bloom et al. (2013) in India, Higuchi et al. (2015) in Vietnam, and Higuchi et al. (2016) in Tanzania. These studies find that training improved treated enterprises' management and business performance.

This study analyzes the impacts of Kaizen training on the management practices and performance of small- and medium-sized enterprises (SMEs) in Vietnam. It also addresses the issue of whether local trainers can gain sufficient skills in training enterprises. The latter is a new issue as explained shortly below. Kaizen and lean manufacturing have so much in common. Both start without capital investment but with what an enterprise has already had. Probably, Kaizen is somewhat more human-friendly and more widely adopted in the developing world (Imai 2012; Hosono 2017; Shimada and Sonobe 2017; Otsuka et al. 2018). Yet, neither Kaizen nor lean manufacturing is known by the majority of enterprises, especially small-scale enterprises, in the developing world. While Japan International Cooperation Agency (JICA) has had a number of projects disseminating Kaizen, only a very few attempts have been made to assess the effectiveness of Kaizen for such enterprises rigorously.

The extent to which Kaizen can be disseminated across the SME sector in developing countries would be limited by the availability of local trainers. It does not seem an easy task to train local trainers so that they can deliver effective training services for local enterprises on their own. This difficulty casts a shadow over the endeavor toward the quick and wide dissemination of management knowledge and skills.

Our study will shed light not only on an enterprise training program provided by local trainers but also on a trainer training (TT) program in which the local trainers are trained. To our knowledge, this study will be among the first to highlight trainer training in the literature on management training. By doing so, this study is hoped to offer some insights into a good design of trainer training.

\section{Design of the Kaizen Training Program AND THE STUdy Site}

\subsection{Trainer Training and Training Material}

\subsubsection{Trainer Training}

A trainer training (TT) was provided to five lecturers of Foreign Trade University, who are in the Faculty of Business Administration. These 
lecturers were all MBA holders and had advanced knowledge in management. Nevertheless, they did not have a deep understanding about Kaizen and skills to be a Kaizen trainer. We, thus, invited one Japanese expert in Kaizen with experiences of teaching Kaizen in developing countries to train these lecturers. The period of TT was from 24 April 2017 to 5 May 2017. While three out of the five local trainers could not complete the TT program, the other two could.

\subsubsection{Training Material}

Training material for the SMEs in Vietnam focused on key elements of Kaizen, of which $5 \mathrm{~S}$ is the most important part. In addition, we provided the enterprises with basic information about business planning, book keeping, and marketing in a manner consistent with the SIYB training.

\subsection{The Study Site}

The study site is Trat Cau village in an outskirt of Hanoi. The production of bedding-related products in the village dates back many years ago. During the 1990s, some Korean companies came to Vietnam to produce high-quality bed matrices, blankets, bed covers, and pillows. People in the village were inspired by the success of the Korean companies and started to produce similar products.

The fine division of labor among enterprises is an important characteristic of the village. Four main groups of products, blankets, bed sheets, pillows, and bed matrices, correspond to four main groups of enterprises. Materials for production are bought from outside of the village and imported from abroad. Products of the village are sold in the domestic market and to all regions in Vietnam.

\subsection{Sampling for the Survey}

We obtained a list of 816 enterprises from the local government office. We selected 195 enterprises that were involved in the production of beddingrelated products, of which 59 were registered enterprises and 136 were unregistered ones. ${ }^{1}$ Out of 59 registered enterprises, there were 7 incorporated companies and 52 limited liabilities companies. Applying a stratified sampling scheme, we randomly selected 32 out of the 59 formal enterprises and 68 out of 136 informal enterprises for both the baseline and post-training surveys. We could not get complete data for three enterprises, leaving us with data for 97 enterprises in our sample. 


\subsection{Questionnaire}

The baseline questionnaire asks questions about the history of enterprises to understand how enterprises were formed, and the personal information of the owners such as education, gender, age, and birthplace as these factors may affect enterprises. We are also interested in the business relationship of the owners with other business owners within their extended families, with whom they might share information, ideas, and even income following the Vietnamese culture.

We have a set of questions to collect data about business practices of the enterprises, including practices of Kaizen. We included questions to ask about sales revenue and costs. We designed the questionnaire to include questions to ask about networking of the owners/managers. In the posttraining survey, we used the same questionnaire as the one used in the baseline survey. However, we included three additional open-ended questions to ask the owners/managers about the evaluation of the training.

\section{Delivery of the Kaizen Training Program}

\subsection{Selection of Treated-and-Control Pairs of Enterprises}

Given our small sample size, we applied the pairwise matching technique proposed by the Bruhn and McKenzie (2009). Gender of the owner of the enterprise, sales revenue, and registration status of the enterprise were used for matching the pairs of treated and control enterprises. Three enterprises, including one registered and two unregistered enterprises, were not paired leaving 94 enterprises in 47 pairs, of which 15 pairs were registered and 32 pairs were unregistered enterprises.

Due to the limited budget that only allows for Kaizen training provision to 40 treated enterprises, we decided to select 15 pairs of registered enterprises and randomly select 25 pairs of unregistered enterprises. This processing made our sample of 40 treated enterprises with 15 registered and 25 unregistered enterprises. Correspondingly, there were 40 control enterprises in pairs with 15 registered and 25 unregistered enterprises.

\subsection{Class-Room Seminar Training}

We conducted the class-room seminar training by inviting 40 treated enterprises to a seminar on 7 September 2017. We sent invitation letters to all 40 treated enterprises and followed by several rounds of phone calls to 
the owners to confirm their participation. Because owners of enterprises were busy with their daily management, only 17 came to the class-room training. For the 23 owners who could not come to the class-room seminar training, we sent our two local trainers to their enterprises to give them the training material and explained to them the content of the material.

\subsection{On-site Training}

The on-site training was conducted in three rounds from 11 to 30 September, from 20 to 31 October, and from 1 to 12 December. Each local trainer was randomly assigned to 20 enterprises in the treated group and the local trainers did not change the enterprises throughout three rounds of training.

For the first round of training, the local trainers spent three hours for each enterprise to analyze the production and production-related issues in the enterprise. After the analysis, the local trainers produced a report for each enterprise. The local trainers then spent two more hours to come back to each enterprise to explain to them what could be done to improve the situation of the workshop. For the second round of on-site training, the process was similar. Total hours of service provided to the enterprises were three hours. The third round of on-site training resembled the second round in terms of content of training, steps of training, and time for training. After each round of training, we sent a person to each treated enterprise to ask them to evaluate the service provided by the local trainers.

\section{Post-Training Survey}

The post-training survey was conducted from 15 to 30 January 2018 . We managed to get information from 79 enterprises as one unregistered enterprise in the control group had closed its business before the survey and refused to participate in the survey. We could interview all 40 owners of the treated enterprises.

\section{Characteristics of Sampled EnTERPrises AND OWNERS}

\subsection{Characteristics of Sample Enterprises}

According to Table 11.1, sales revenue of the 40 paired control enterprises in 2016 was higher than that of the treated enterprises. Nevertheless, the 
differences are not statistically significant at any conventional significant levels. There is no significant difference in gender among owners of the treated and paired control enterprises. This observation is not out of expectation as we applied the pairwise matching method to randomly select the treated and control enterprises.

Out of 35 business practices, the treated and control enterprises all performed on average about $18 \%$ of the number of business practices in 2016. Even though we have not introduced the Kaizen training program to the enterprises in 2016, some of them have already implemented some Kaizen practices in their businesses. The incidence and extension of applying Kaizen practices are also not statistically significantly different among the treated and control enterprises.

\subsection{Who Participated in the Kaizen Training Program?}

Table 11.1 also compares basic characteristics of the owners of the treated and control enterprises. On average the owners graduated from upper secondary schools. Half of the owners had prior experience in the industry before taking the management of their enterprises and few of them had training related to their production before. Almost all of the owners are indigenous people who were born in the village. Similar to other village industries in Vietnam ( $\mathrm{Vu}$ et al. 2009, 2010), most of the owners have parents having worked in the same industry before and have their siblings and siblings-in-law who are running businesses in the industry. Only a few of the owners have been abroad for the purpose of doing business. This is not surprising because they can easily buy machine and materials in the domestic market and they only sell their products domestically.

\section{Evaluation of the Kaizen Training Program}

\subsection{Estimation Method}

We applied the treatment effect on the treated (TOT) estimation in this study. The TOT estimates show effects of the Kaizen training program on outcomes of the enterprises randomly selected and participated in the program. These outcomes include willingness-to-pay, business practice score, and business performance. We measure performance of enterprises by several indicators including sales revenue, value added, and gross profit. Value added is calculated as by subtracting material cost and other intermediate 
Table 11.1 Mean of major characteristics of the sampled enterprises and their owners in 2016

\begin{tabular}{lll}
\hline & Treated enterprises & $\begin{array}{l}\text { Paired control } \\
\text { enterprises }\end{array}$ \\
\hline Characteristics of the sampled enterprises & & \\
Sales revenue (million VND) & 5608.1 & 5757.6 \\
Ratio of male owner & 0.73 & 0.73 \\
Ratio of enterprise being registered as a company & 0.33 & 0.33 \\
Business practice score (BSC) (out of 35) & 6.57 & 6.43 \\
Kaizen practice score (KSC) (out of 20) & 3.63 & 3.83 \\
Value of inventory & 312.2 & 354.5 \\
Years of operation & 11.7 & 8.9 \\
Initial number of workers & 3.1 & 2.4 \\
Initial amount of capital invested (million VND) & 1022.2 & 524.7 \\
Ratio of enterprises inherited from parents & 0.18 & 0.25 \\
Characteristics of the owners & & \\
Age (years) & 39.5 & 39.0 \\
Years of education & 9.5 & 10.0 \\
Having prior experience in the industry & 0.5 & 0.4 \\
Training experience & 0.175 & 0 \\
Being born within the village & 1.00 & 0.97 \\
Having been abroad for business-related trip & 0.08 & 0.07 \\
Parents used to work in the industry & 0.88 & 0.85 \\
Number of blood siblings working in the industry & 3.30 & 2.88 \\
Number of siblings-in-law working in the industry & 2.23 & 2.37 \\
Number of enterprises & 40 & 40 \\
\hline
\end{tabular}

costs from sales revenue. Gross profit is equal to value added minus labor cost. As we expect that application of Kaizen practices will help improve productivity of the enterprises, we also measure their performance by calculating labor productivity, which is value added divided by the total number of working months of permanent workers. The calculation of labor productivity requires taking the owner and his or her spouse as permanent workers because they always participate in daily management and production of their enterprises. This inclusion also helps to avoid a problem of some enterprises that do not employ any workers. During the Kaizen training program, we emphasized the reduction of inventory as an important practice to reduce cost. We, thus, take the reduction in the number of products in inventory as an indicator to measure performance of enterprises. Additionally, we analyze the current value of products in inventory 
to see how enterprises improve management of inventory as they often have multiple kinds of products.

The estimate of the TOT can be obtained by the following regression:

$$
y_{i t}=\alpha_{0}+\alpha_{1} P_{i t}+\alpha_{2} S_{i t}+\alpha_{3} X_{i t}+u_{i}+\gamma_{t}+\varepsilon_{i t},
$$

where $y_{i t}$ is the outcomes of enterprise $i$ at time $t$, which is before the Kaizen training program or after the Kaizen training program, containing performance of enterprises and quality of management, which will be explained below; $P_{i t}$ is the participated or treated status dummy that is equal to 1 if enterprise $i$ participated in the Kaizen training program and 0 otherwise; $S_{i t}$ is a dummy variable for business communication of the owners of enterprises, which takes the value of 1 if the owner of enterprise $i$ talked with the owner of any treated enterprise and 0 otherwise $^{2} ; X_{i t}$ is a vector of variables representing the characteristics of enterprise $i$ and of the owner of enterprise $i$, of which many are time-invariant in our sample; $u_{i}$ is the fixed effect of enterprise $i ; \gamma_{t}$ is the time effect common to all the enterprises; and $\varepsilon_{i t}$ is an error term.

To estimate Eq. (11.1), we applied the Fixed-effects or Randomeffects model. ${ }^{3}$ Our main variable of interest is $P_{i t}$. We expect that $\alpha_{1}$ will be statistically greater than zero, meaning that the Kaizen training program has positive effects on various indicators of outcomes of the treated enterprises.

Our questionnaire included a set of detailed questions about different business practices including business records, quality improvement, labor management, marketing activities, and Kaizen-related practices in both prior and post-training surveys. We follow Bloom et al. (2011), De Mel et al. (2012), Suzuki et al. (2014), and Higuchi et al. (2015) to construct a Kaizen practice score (KSC) from a subset of these indicators, which are directly related to the main content of the Kaizen training program. During each survey, we counted how many of the 20 Kaizen practices each sample enterprise has adopted by the time of the survey. ${ }^{4}$ We used these indices to proxy for the quality of management of the enterprises.

In this study, to measure performance of enterprises apart from sales revenue, we used value added and labor productivity. Labor productivity is measured as value added divided by the total working months of all permanent workers including the owner and his or her spouse. 


\subsection{Effects on Willingness-to-Pay of the Owners}

We collected data about willingness-to-pay for the Kaizen training program by asking all the owners of enterprises a question: "Are you willing to pay 3 million VND (about 132 USD using the official exchange rate as of 2017) to participate in the Kaizen training program" after briefly explaining the main content of the Kaizen training program. We asked the same question to the owners in both surveys before and after the Kaizen training program. This is a hypothetical question and the owner does not actually have to pay to participate in the training program if his or her answer is yes. As a result, answers to this question can exaggerate demand for the training program. We follow Blumenschein et al. (2008) and Suzuki et al. (2014) to reduce this exaggeration by further asking the respondents whether they are sure about their answer. We ask them: "Are you definitely sure about your answer?" and their answer could be either "definitely sure" or "probably sure." We took the "definitely sure" answer as the affirmative one.

Table 11.2 presents the estimation of the willingness-to-pay of the owners. We pooled the data for the regression in Column 1. Column 2 shows the intention-to-treat (ITT), which is the same as TOT, estimation with the Fixed-effects model. The coefficients of the variable for participating in the Kaizen training programs are all positive and significant at $1 \%$ significance level. The estimation results confirm our expectation that the Kaizen training program increases the willingness-to-pay of the owners. The high appreciation of the training program is not only among the owners who have never attended any other training programs but also among those who have attended other training programs before. This finding is similar to results in other previous studies in other locations in Vietnam (e.g., Suzuki et al. 2014). It, thus, confirms the unawareness of many entrepreneurs, especially of small- and medium-sized enterprises, in developing countries like Vietnam about importance of management training. Also, the finding shows that our Kaizen training program was successfully conducted. The program has raised awareness of the entrepreneurs about management knowledge and skills.

\subsection{Effects on Kaizen Practices of Enterprises}

Tables 11.3 reports the TOT impacts of the Kaizen training program on the Kaizen practice score (KSC). Columns 1 and 2 in Table 11.3 show 
Table 11.2 Willingness-to-pay of the owners

\begin{tabular}{|c|c|c|}
\hline & $\begin{array}{l}\text { (1) } \\
\text { Pooled }\end{array}$ & $\begin{array}{l}\text { (2) } \\
\text { Fixed effects }\end{array}$ \\
\hline $\begin{array}{l}\text { Participated in the Kaizen training program dummy } \\
\text { (yes = 1) }\end{array}$ & $\begin{array}{l}0.485 * * * \\
(5.90)\end{array}$ & $\begin{array}{l}0.496 * * * \\
(6.03)\end{array}$ \\
\hline $\begin{array}{l}\text { Talked with treated enterprises about Kaizen dummy } \\
(\text { yes = 1) }\end{array}$ & $\begin{array}{l}0.029 \\
(0.31)\end{array}$ & $\begin{array}{l}0.033 \\
(0.35)\end{array}$ \\
\hline Registration status dummy (company $=1)$ & $\begin{array}{l}0.064 \\
(1.07)\end{array}$ & \\
\hline Years of operation & $\begin{array}{l}0.003 \\
(0.77)\end{array}$ & \\
\hline $\begin{array}{l}\text { Who established the enterprise dummy (parent }=1 \text {; } \\
\text { own=)? }\end{array}$ & $\begin{array}{l}0.009 \\
(0.15)\end{array}$ & \\
\hline Initial number of workers & $\begin{array}{l}0013 \\
(1.45)\end{array}$ & \\
\hline Initial capital invested & $\begin{array}{l}0.001 \\
(0.30)\end{array}$ & \\
\hline Age of owner (years) & $\begin{array}{l}-0.004 \\
(1.29)\end{array}$ & \\
\hline Gender of owner dummy (male = 1 ) & $\begin{array}{l}0.070 \\
(1.43)\end{array}$ & \\
\hline Years of schooling of owner & $\begin{array}{l}-0.004 \\
(0.61)\end{array}$ & \\
\hline Birthplace of owner dummy (in village = 1 ) & $\begin{array}{l}-0.104 \\
(1.46)\end{array}$ & \\
\hline Prior job related to the industry dummy $($ Yes $=1)$ & $\begin{array}{l}-0.029 \\
(0.66)\end{array}$ & \\
\hline Parents having worked in the industry dummy $($ Yes $=1)$ & $\begin{array}{l}-0.035 \\
(0.48)\end{array}$ & \\
\hline No. of blood siblings in the industry & $\begin{array}{l}0.002 \\
(0.14)\end{array}$ & \\
\hline No. of in-law siblings in the industry & $\begin{array}{l}0.001 \\
(0.06)\end{array}$ & \\
\hline $\begin{array}{l}\text { Having been trained about doing business in the industry } \\
\text { dummy (yes = 1) }\end{array}$ & $\begin{array}{l}0.001 \\
(0.00)\end{array}$ & \\
\hline $\begin{array}{l}\text { Having been abroad for business-related purpose dummy } \\
\text { (yes }=1 \text { ) }\end{array}$ & $\begin{array}{l}-0.024 \\
(0.27)\end{array}$ & \\
\hline Year dummy $(2017=1)$ & $\begin{array}{l}0.001 \\
(0.02)\end{array}$ & $\begin{array}{l}-0.007 \\
(0.11)\end{array}$ \\
\hline Constant & $\begin{array}{l}0.893 \\
(0.02)\end{array}$ & $\begin{array}{l}13.663 \\
(0.11)\end{array}$ \\
\hline No. of observations & 159 & 159 \\
\hline No. of groups & & 80 \\
\hline$R$-squared/R-squared overall & 0.48 & \\
\hline
\end{tabular}

Notes: Absolute values of $t$-statistics are in the brackets (robust $t$-statistics is in Columns 1 and 2 ). *, **, *** present $10 \%, 5 \%$, and $1 \%$ statistically significant levels, respectively 
that the training program significantly increased the Kaizen practice score by about $0.76-1.03$ points (out of 20 points).

Table 11.3 additionally presents the effects of exchanging information about Kaizen practices among the owners. The dummy for discussing about Kaizen practices with the treated enterprises has positive and statistically significant coefficients in Table 11.3. The magnitude of these coefficients is similar to that of the coefficients of the variable for participation of the owners in the Kaizen training program. This result is not surprising as our training program focused mainly on Kaizen management practices. This finding suggests that good management practices not only were adopted by participation in the training program but could also be acquired through exchanging information within the network of the enterprise owners in the village. In other words, our training program has shown a spillover effect among the non-treated enterprises. Spreading of good management practices among family relatives, friends, and neighbors is an important mechanism to sustain impacts of training program in developing countries, where a dense social network exists. Such rapid spreading of Kaizen management practices among enterprises in this village is nothing but a result of information spillovers, which has been considered one of the advantages of enterprises being located in industrial clusters since Marshall (1920).

Column 1 in Table 11.3 provides more information about effects of the social network of the owners on their adoption of Kaizen management practices. The dummy variable for the enterprises having been inherited from parents has negative but not statistically significant in Column 1 . The dummy variable for the owners whose parents used to work in the same industry has negative and highly statistically significant coefficients in Column 1. Similarly, the coefficient of the dummy variable for the owners having born in the village is negative and highly statistically significant in Column 1. These findings indicate that the owners who had been influenced more heavily by their parents and by their family relatives applied more traditional management style than their counterparts. In other words, having been born in the village and having been influenced by previous generations of owners including their parents is an important determinant of lower application of Kaizen management practices, which are more modern than traditional management practices.

In contrast, in Column 1 in Table 11.3 the variable for the number of blood siblings of the owners, who are doing similar businesses in the industry, has positive and significant effect on the adoption of Kaizen 
Table 11.3 Effects of the Kaizen training program on Kaizen practice score (KSC)

\begin{tabular}{|c|c|c|}
\hline & $\begin{array}{l}\text { (1) } \\
\text { Pooled }\end{array}$ & $\begin{array}{l}\text { (2) } \\
\text { Fixed effects }\end{array}$ \\
\hline $\begin{array}{l}\text { Participated in the Kaizen training program dummy } \\
(\text { yes = 1) }\end{array}$ & $\begin{array}{l}0.756 * \\
(1.87)\end{array}$ & $\begin{array}{l}1.025 * * * \\
(2.64)\end{array}$ \\
\hline $\begin{array}{l}\text { Talked with treated enterprises about Kaizen dummy } \\
(\text { yes }=1)\end{array}$ & $\begin{array}{l}1.222 * * \\
(2.38)\end{array}$ & $\begin{array}{l}0.911 * * \\
(2.08)\end{array}$ \\
\hline Registration status dummy (company $=1)$ & $\begin{array}{l}3.595 * * * \\
(9.70)\end{array}$ & \\
\hline Years of operation & $\begin{array}{l}0.042 * * \\
(2.50)\end{array}$ & \\
\hline $\begin{array}{l}\text { Who established the enterprise dummy (parent }=1 \text {; } \\
\text { own=)? }\end{array}$ & $\begin{array}{l}-0.382 \\
(1.07)\end{array}$ & \\
\hline Initial number of workers & $\begin{array}{l}0.086 \\
(1.50)\end{array}$ & \\
\hline Initial capital invested & $\begin{array}{l}-0.020 * \\
(1.69)\end{array}$ & \\
\hline Age of owner (years) & $\begin{array}{l}-0.038 * * \\
(2.31)\end{array}$ & \\
\hline Gender of owner dummy $($ male $=1)$ & $\begin{array}{l}-0.344 \\
(1.21)\end{array}$ & \\
\hline Years of schooling of owner & $\begin{array}{l}-0.034 \\
(0.72)\end{array}$ & \\
\hline Birthplace of owner dummy (in village $=1$ ) & $\begin{array}{l}-2.150 * * * \\
(3.12)\end{array}$ & \\
\hline Prior job related to the industry dummy (yes $=1$ ) & $\begin{array}{l}-0.315 \\
(1.08)\end{array}$ & \\
\hline Parents having worked in the industry dummy (yes = 1) & $\begin{array}{l}-0.931 * * * \\
(2.63)\end{array}$ & \\
\hline No. of blood siblings in the industry & $\begin{array}{l}0.212 * * * \\
(2.95)\end{array}$ & \\
\hline No. of in-law siblings in the industry & $\begin{array}{l}-0.008 \\
(0.09)\end{array}$ & \\
\hline $\begin{array}{l}\text { Having been trained about doing business in the industry } \\
\text { dummy (yes = 1) }\end{array}$ & $\begin{array}{l}-0.292 \\
(0.38)\end{array}$ & \\
\hline $\begin{array}{l}\text { Having been abroad for business-related purpose dummy } \\
\text { (yes }=1 \text { ) }\end{array}$ & $\begin{array}{l}1.322 * * * \\
(2.44)\end{array}$ & \\
\hline Year dummy $(2017=1)$ & $\begin{array}{l}0.503 * \\
(1.83)\end{array}$ & $\begin{array}{l}0.454 \\
(1.58)\end{array}$ \\
\hline Constant & $\begin{array}{l}-1007.085 * \\
(1.82)\end{array}$ & $\begin{array}{l}-911.572 \\
(1.57)\end{array}$ \\
\hline No. of observations & 159 & 159 \\
\hline No. of groups & & 80 \\
\hline$R$-squared $/ R$-squared overall & 0.65 & 0.08 \\
\hline
\end{tabular}

Notes: Absolute values of $t$-statistics are in the brackets (robust $t$-statistics is in Columns 1 and 2).*, **, *** present $10 \%, 5 \%$, and $1 \%$ statistically significant levels, respectively 
practices. ${ }^{5}$ It is also noted that the age of the owner variable is negative and significant in all regressions. The production organization of old enterprises in the village, of which many have been established by parents of the current owners, was only based on experience of the previous generation. Modern business practices in general and Kaizen management practices in particular were largely unknown to the owners of this old generation. Recently, together with the open and development of the economy of Vietnam, new management practices have been imported from abroad. The current generation of owners has gradually had access to such new management practices and adopted them. Therefore, these findings in Table 11.3 suggest that many of the owners in the village who inherited the businesses from their parents and are influenced by the experience and the old management style of their previous generation tend to be lacking information of and/or unaware of the value of Kaizen management practices.

Column 1 in this table also shows that formal or registered enterprises adopted more Kaizen management practices than informal or unregistered enterprises. The former had 3.5 points in the Kaizen practice score (out of 20 points) higher than the latter. It is reasonable to observe this finding as formal or registered enterprises tend to have better capacity to adopt Kaizen management practices.

In addition, the dummy variable for the owners who have attended other business-related training programs before has negative but not statistically significant coefficient in Column 1 in Table 11.3. This finding indicates that previous training programs attended by the owners might have not focused on Kaizen management practices. Therefore, our Kaizen training program was new to them. ${ }^{6}$

In order to qualitatively assess the impacts of the Kaizen training program, during the post-training survey we asked the owners open-ended questions to see how they perceived about benefits and challenges of adopting Kaizen management practices. As presented in Table 11.4, not all owners fully understood what Kaizen management practices can bring about and not all of them have actually implemented all elements of Kaizen yet. Nevertheless, many of them have started to apply and realize the benefits of Kaizen management practices for their businesses in different aspects. Particularly many of them reported that the adoption of Kaizen management practices helped them arrange materials, parts, and final products more neatly and more organized. As a result, they themselves and their workers could easily identify production areas. Better arrangement 
Table 11.4 Summary of benefits and challenges from Kaizen adoption reported in 2017

$\begin{array}{lc}\text { Benefits } & 10 \\ \text { Arranged, neat, well organized } & 2 \\ \text { Saving materials } & \\ \text { Easy to know the production areas; easy for searching things; saving time and cost } & 14 \\ \text { to search for materials, parts, tools, and products } & 3 \\ \text { Removal of unused things; more space for production } & 2 \\ \text { More production; more profit } & 5 \\ \text { Clean; saving time and cost to remove dust and waste from products } & 1 \\ \text { More responsible workers } & 2 \\ \text { Faster movement of materials and products } & 5 \\ \text { Will be very useful in the future when production is expanded } & \\ \text { Challenges } & 13 \\ \text { Workers do not follow instruction; workers think their experience is good } & 6 \\ \text { enough; workers are not discipline, not responsible; frequent job quitting } & 4 \\ \text { Have not found effective ways to encourage and force workers to apply Kaizen } & \\ \text { Characteristics of the production and need to serve orders quickly results in messy } & 4 \\ \text { workshops and difficulty in applying Kaizen } & 6 \\ \text { Not enough space; small scale so that Kaizen application is not efficient } & 1 \\ \text { There is nobody to implement Kaizen } & 2 \\ \text { Shortage of capital leads to underinvestment in tools, space } & \\ \text { Kaizen is useful only in some certain stages of production } & 1 \\ \text { Many workers are not in fixed shifts } & 1 \\ \text { Gradual improvement from Kaizen so that the effect cannot be realized } & 2 \\ \text { immediately } & \\ \text { There is no difficulty } & \end{array}$

Note: Numbers in the tables show the frequency of the answers

reduced time to search for materials, spare parts, tools, and final products. Also, implementation of $5 \mathrm{~S}$ reduces waste and cost. Interestingly, 5 out of 40 owners shared their views about would-be benefits of Kaizen management practices by mentioning that they believe Kaizen management practices will be useful for them in the future when their businesses are expanded. Such awareness of the owners is a good sign of sustaining the impacts of Kaizen management practices.

Many difficulties in applying Kaizen practices have also been reported by the owners. Among these, the notable difficulty is related to the work attitude and discipline of workers. As most of workers have just quit farming and some of them are even farming part-time, they are not well trained to be industrial workers. Also, enterprises in the village are competing with each other for labor so that workers' turnover rate is high and workers' 
commitment is low. Additionally, lack of knowledge to motivate and control workers is considered a major weakness of many owners in the village. As a result, many owners indicated during our survey that it is not easy to implement and sustain Kaizen even though they are aware of benefits of Kaizen management practices after the training. This finding suggests that our future training (if any) to the enterprises should contain an element on labor management to be more effective. Other challenges including limited space for implementing Kaizen management practices, lack of capital, and gradual impacts of Kaizen management adoption have also been mentioned by the owners during our survey. ${ }^{7}$

\subsection{Effects on Performance of Enterprises}

We estimated the effects of participation in the Kaizen training program on performance of the enterprises, which are measured by sales revenue, value added, and labor productivity, for paired sample enterprises. Results of the estimation are presented in Table 11.5. According to this table, participation in the Kaizen training program did not help the treated enterprises to have higher sales revenue or value added. It is not out of our expectation as we conducted the post-training survey right after providing the on-site training. As such, it was too soon for the training program to have any effect on the operation size measured by sales revenue or value added of the enterprises. This finding is consistent with other previous studies (Suzuki et al. 2014; Higuchi et al. 2015). ${ }^{8}$

We could, however, detect that participation in the training program has positive effect on labor productivity as the coefficient of the variable for participating in the training program is positive and statistically significant in Column 6. The treated enterprises might have utilized workers more efficiently to get higher labor productivity after having participated in the training program. Another aspect we have focused on during the training program is to help the owners cut operation costs and reduce waste by lowering inventory. As the production in the village is still seasonal due to the nature of the products and weather in different locations in Vietnam, stocking products for sales during winter is often practiced by the enterprises. Given limited space for production in many enterprises, such inventory creates high costs during production. Findings in Table 11.5 suggest that the treated enterprises have adopted the idea of reducing the value of inventory after the training program more than the enterprises in the control group. Findings on the immediate significant 


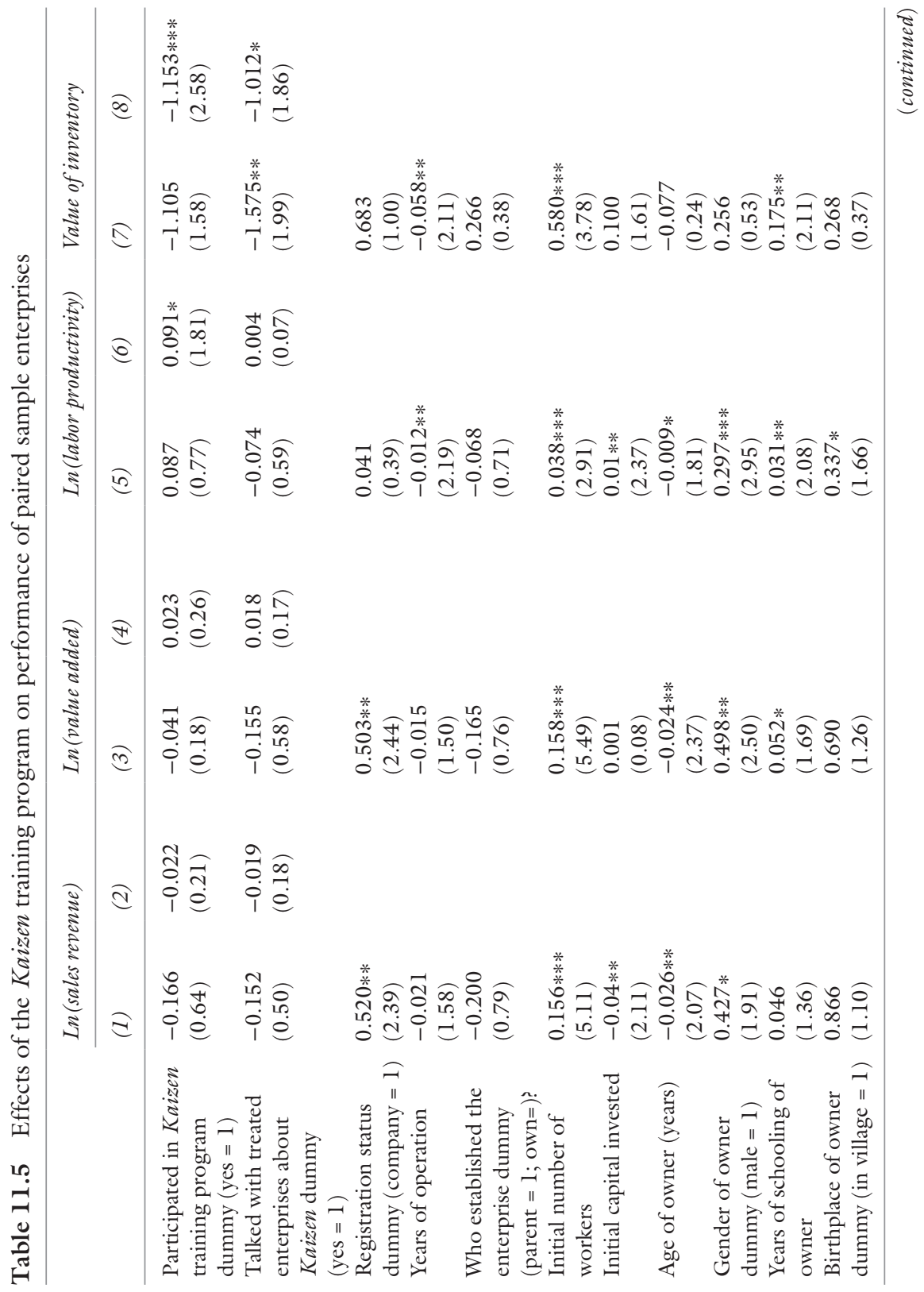




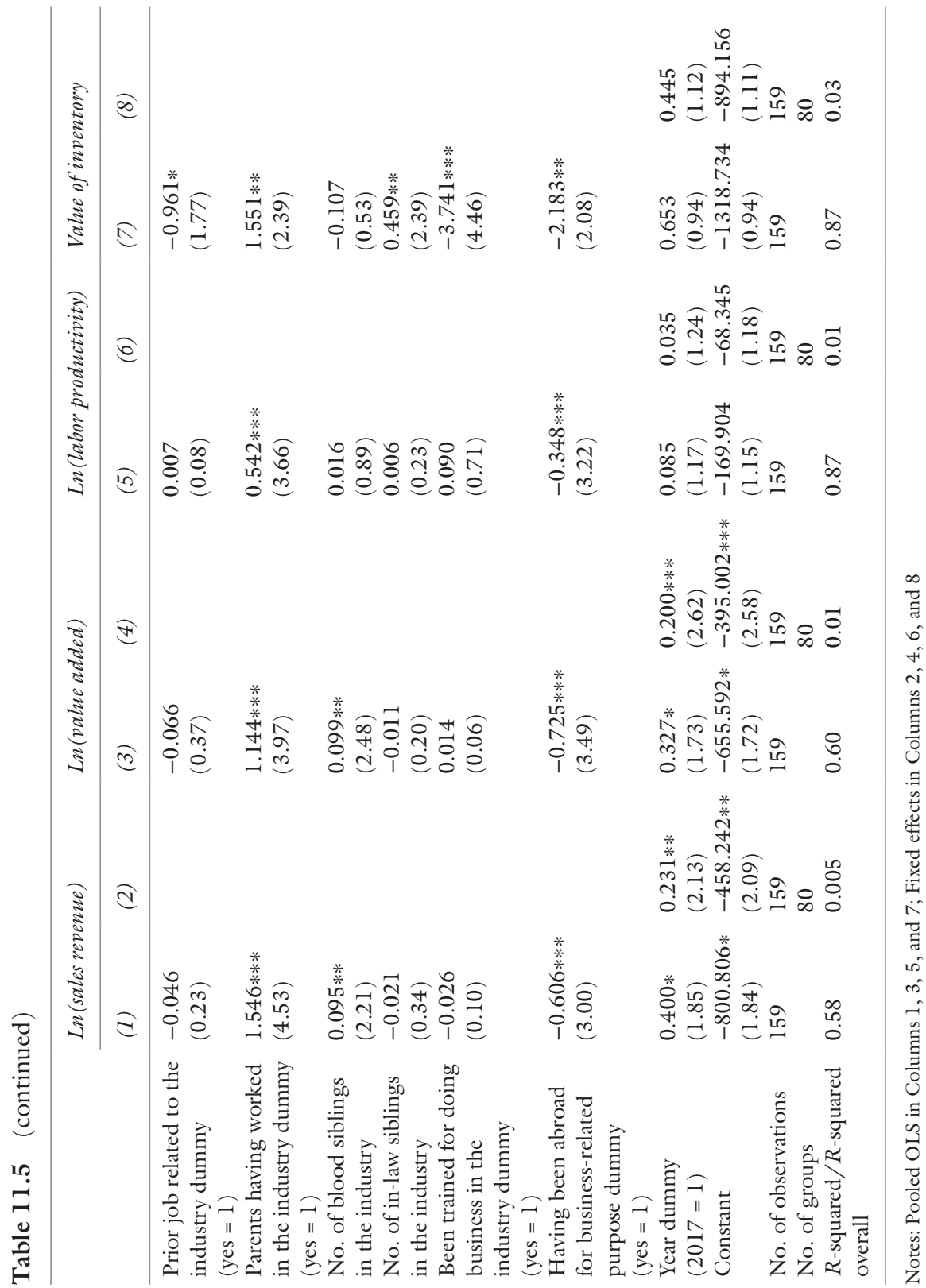


effects of the Kaizen training program on management practices and performance of the treated enterprises, even though still limited, confirm the effectiveness and success of our training program.

\section{Concluding Remarks}

In this chapter, we have analyzed experimentally the impacts of a Kaizen management training program on management practices and performance of small- and medium-sized enterprises in a rural village in Northern Vietnam. Firstly, we showed that training of local trainers could be possible to bring Kaizen management practices to small- and medium-sized enterprises in the rural area in a transition economy like Vietnam. It is, thus, practically feasible to scale up and spread Kaizen management practices to other enterprises in other locations at a more affordable cost. Secondly, we find that the owners of the enterprises are inheriting old management practices from their previous generation and are unaware of value of management training ex ante. Our Kaizen training program, which was conducted by the local trainers who have attended the TOT training by a foreign expert, has changed enterprises' willingness-to-pay for management knowledge. Thirdly, we discover that the training program did indeed improve business practices of the owners in two ways, through direct participation in the training program and through exchanging ideas and discussing with their peers about the management practices. Finally, we find that the adoption of Kaizen management training is conditional on many factors of which labor management is important. These findings indicate that the provision of Kaizen management training, which is often expensive, in developing countries can be sustained through TOT training to the local trainers and through an existing dense social network where people interact and exchange information with each other.

\section{NoTes}

1. In Vietnam, registered enterprises are registered under the Law of Enterprise (Ministry of Justice 2014). Registered enterprises are in the form of stateowned enterprises, incorporations, or limited liability companies and often have larger operation size. Unregistered enterprises are in the form of household enterprises with smaller operation size. Registered enterprises can export and import directly and can issue value added tax invoices when selling their products. Registered enterprises have to pay corporate income 
tax, while unregistered enterprises do not. Therefore, both types of enterprises coexist.

2. Having dense social networks is an important characteristic of many villagebased industrial clusters in Vietnam. The networks might be created from kinship among relatives in extended families or from friendship among people who have been living close to one another for years. We also constructed this business communication variable by further identifying whether the owner of enterprise has talked with his or her counterpart in the treated enterprises about Kaizen.

3. The Hausman test will be performed to select one of the two models.

4. Description of the questions used to collect data to calculate these scores is provided upon request.

5. We assume that the management practices of the current-generation owners are better than the management practices of the old-generation owners.

6. This finding is consistent with information we have obtained from interviews with the owners that almost all of them have never got any training on Kaizen management before. Some of them attended management training programs having been organized outside of the village on issues related to business management but not specifically on Kaizen management.

7. In fact, 6 owners out of 40 treated ones mentioned about limited space for Kaizen management adoption. These owners might have misunderstood the benefits of Kaizen management practices, which will create more space for production through better arrangement.

8. We are planning to conduct additional rounds of survey of the enterprises in the village to study longer-term impacts of the training program on operation size of the enterprises. We hope to be able to show positive impacts of the training program on sales revenue and value added of the treated enterprises in the near future.

\section{REFERENCES}

Bloom, Nicholas, Benn Eifert, Aprajit Mahajan, David McKenzie, and John Roberts. 2011. Does Management Matter? Evidence from India. Working Paper No. 16658. NBER, Cambridge, MA.

. 2013. Does Management Matter? Evidence from India. Quarterly Journal of Economics 128 (1): 1-51.

Bloom, Nicholas, Christos Genakos, Raffaella Sadun, and John Van Reenen. 2012. Management Practices across Firms and Countries. Academy of Management Perspective 26 (1): 12-33.

Blumenschein, Karen, Glenn Blomquist, Magnus Johannesson, Nancy Horn, and Patricia Freeman. 2008. Eliciting Willingness to Pay Without Bias: Evidence from a Field Experiment. Economic Journal 118 (Jan.): 114-137. 
Bruhn, Miriam, and David McKenzie. 2009. In Pursuit of Balance: Randomization in Practice in Development Field Experiment. American Economic Journal: Applied Economics 1 (4, Oct.): 200-232.

De Mel, Suresh, David McKenzie, and Christopher Woodruff. 2012. Business Training and Female Enterprise Start-up, Growth, and Dynamics: Experimental Evidence from Sri Lanka. World Bank Policy Research Working Paper No. 6145.

Drexler, Alejandro, Greg Fischer, and Antoinette Schoar. 2014. Keeping It Simple: Financial Literacy and Rules of Thumb. American Economic Journal: Applied Economics 6 (2, Apr.): 1-31.

Higuchi, Yuki, E. Paul Mhede, and Tetsushi Sonobe. 2016. Short and Longer Run Impacts of Kaizen Management Training: The Case in Tanzania. A Paper Presented at the Annual Bank Conference on Development Economics 2016, World Bank, Washington, DC, June 20-21, 2016.

Higuchi, Yuki, Vu H. Nam, and Tetsushi Sonobe. 2015. Sustained Impacts of Kaizen Training. Journal of Economic Behavior \& Organization 120 (Dec.): 189-206.

Hosono, Akio. 2017. Industrial Strategies: Toward a Learning Society for Quality Growth. In Efficiency, Finance, and Varieties of Industrial Policy: Guiding Resources, Learning, and Technology for Sustained Growth, ed. Akio Noman and E. Joseph Stiglitz. New York: Columbia University Press.

Imai, Masaaki. 2012. Gemba Kaizen: A Commonsense Approach to Continuous Improvement Strategy. 2nd ed. New York: McGraw-Hill.

Karlan, Dean, and Martin Valdivia. 2011. Teaching Entrepreneurship: Impact of Business Training of Microfinance Clients and Institutions. Review of Economics and Statistics 93 (2): 510-527.

Marshall, Afred. 1920. Principles of Economics. London: Macmillan, now Palgrave Macmillan.

McKenzie, David, and Christopher Woodruff. 2014. What Are We Learning from Business Training and Entrepreneurship Evaluations around the Developing World? World Bank Research Observer 29: 48-82.

Ministry of Justice. (2014). Luật Doanh nghiệp. Accessed June 26, 2018. http:// www.moj.gov.vn/vbpq/lists/vn\%20bn\%20php\%20lut/view_detail. aspx?itemid $=30314$.

Otsuka, Keijiro, Kimiaki Jin, and Tetsushi Sonobe. 2018. Applying the Kaizen in Africa-A New Avenue for Industrial Development. Palgrave Macmillan.

Shimada, Go, and Tetsushi Sonobe. 2017. Impacts of Kaizen Management on Workers: Evidence from the Central America and Caribbean Region. JICA-RI Working Papers, No. 173.

Suzuki, Aya, H. Nam Vu, and Tetsushi Sonobe. 2014. Willingness to Pay for Managerial Training: A Case from the Knitwear Industry in Vietnam. Journal of Comparative Economics 42 (3, Aug.): 693-707. 
Vu, H. Nam, Tetsushi Sonobe, and Keijiro Otsuka. 2009. An Inquiry into the Transformation Process of Village-based Industrial Cluster: The Case of an Iron and Steel Cluster in Northern Vietnam. Journal of Comparative Economics 34 (4, Dec.): $568-581$.

- 2010. An Inquiry into the Development Process of Village Industries: The Case of a Knitwear Cluster in Northern Vietnam. Journal of Development Studies 46 (2): 312-330.

Open Access This chapter is licensed under the terms of the Creative Commons Attribution 4.0 International License (http://creativecommons.org/licenses/ by $/ 4.0 /$ ), which permits use, sharing, adaptation, distribution and reproduction in any medium or format, as long as you give appropriate credit to the original author(s) and the source, provide a link to the Creative Commons licence and indicate if changes were made.

The images or other third party material in this chapter are included in the chapter's Creative Commons licence, unless indicated otherwise in a credit line to the material. If material is not included in the chapter's Creative Commons licence and your intended use is not permitted by statutory regulation or exceeds the permitted use, you will need to obtain permission directly from the copyright holder.

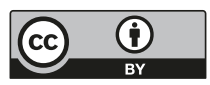

